\title{
Gene therapy gets double dose of screening
}

Tokyo. The human applications of gene therapy seem set to become the latest victim of the bureaucratic walls that separate the various ministries of Japan's central government in Tokyo.

Last week, a newly established gene therapy screening committee of Niigata University, a national university on the coast of the Japan Sea, gave its conditional approval to Japan's first non- therapeutic gene marker experiments to be carried out on humans, which may mark Japan's first step towards gene therapy.

But the experiments, which are similar to those carried out by French Anderson and Steven Rosenberg on cancer patients in the United States nearly five years ago, will probably need to be approved by two separate committees - one under the Ministry of Education, Science and Culture, and the other under the Ministry of Health and Welfare - before they can proceed. This bureaucratic duplication of effort will inevitably delay the Niigata experiments, as well as similar experiments elsewhere.

The proposed experiments will be carried out by Yoshiaki Moriyama, chief of the university's division of bone marrow transplantation, in collaboration with Genetic Therapy Inc., a US company established by French Anderson.

Human stem cells (CD34+ cells) and residual leukaemic cells in bone marrow taken from leukaemia patients in remission will be marked with the bacterial gene for neomycin resistance (Neo-R) after the bone marrow has been purged of most tumour cells by heat treatment.

After transplantation back to the patient, the marked cells will be used to determine if any recurrence of cancer in the patients is caused by residual malignant cells in the purged marrow, or by cells in the patient. Genetic Therapy Inc. will provide the retrovirus vectors for gene marking.

The experiments will use the same marker gene as that used by Anderson and Rosenberg. Very similar gene marker experiments in bone marrow transplants have already been carried out by Malcolm Brenner at St Jude's Children's Research Hospital in the United States. But Brenner used unpurged bone marrow.

Moriyama and Niigata University followed the guidelines established last year by the Ministry of Health and Welfare in drawing up a research plan and screening the experiment. In line with the guidelines, the university also expanded its ethics committee into a larger gene therapy screening committee, with about ten members.

After eight months of deliberations, the committee gave approval for the experiments last week on condition that an application is made for each patient and their informed consent is obtained.

The university, however, comes under the jurisdiction of the Ministry of Education, Science and Culture, which has not yet established guidelines for gene therapy research, or a committee to screen applications for such research.

Furthermore, as the experiments involve clinical trials on humans, officials of the

\section{Nuclear relics are finally junked}

More than 200 metres of top quality 2-metre diameter steel tubing (pictured right) is just one of the unusual items discarded by the Los Alamos $\mathrm{Na}$ tional Laboratory that have found their way to Ed Grothus's nuclear salvage yard near the New Mexico laboratory.

The vacuum tubing, finished to mirror perfection on the inside, was used to direct laser beams at hydrogen isotopes in the Antares experiment, part of the laboratory's nuclear fusion research programme.

Grothus picked up the 125 tonnes of steel when the experiment failed and stored it in the car park of a disused supermarket. Several years later he sold part of the Antares stock back to the laboratory for a Strategic Defense Initiative project. The rest has since been cut up for scrap.

Grothus, a machinist at the laboratory

\section{IMAGE UNAVAILABLE FOR COPYRIGHT REASONS}

for 20 years, began to buy obsolete pieces of equipment from auctions in 1969. Sometimes he sold his purchases on. But most were hoarded in anticipation of the construction of a 14-storey museum, planned as a catalogue of the nuclear age.

Unfortunately pressure from the local fire marshal and the Environmental Protection Agency have forced Grothus to sell up with the dream unrealized.
Ministry of Health and Welfare believe that approval must also be sought from a committee of their ministry.

The health and welfare ministry is expected to announce the members of its advisory committee on gene therapy this week. There will be almost 20 members, including university professors, medical doctors, novelists, journalists and philosophers.

Moving more slowly off the mark, the education ministry has started approaching members of this committee asking them to join its own committee. The number of people in Japan with the expertise needed to pass judgement on such experiments is limited, and many observers expect there to be considerable overlap between the two committees. Nevertheless, it appears that Niigata University will probably require approval from both.

It is not clear which committee will have ultimate authority to reject or accept applications from university researchers. But, according to one scientist involved in setting up the government guidelines, the Ministry of Health and Welfare is unlikely to "embarrass" colleagues in the education ministry by rejecting an application that the education ministry has approved.

Researchers involved in gene therapy research criticize such duplication of effort as "bureaucratic nonsense". They would have far preferred the two ministries to have formed a single joint committee.

David Swinbanks

\section{US abandons planned AIDS vaccine trial}

Washington. The US Department of Defense (DoD) has abandoned its controversial proposal to carry out a large-scale, \$20-million trial of a gp160 therapeutic vaccine for AIDS developed by the Connecticut-based biotechnology company MicroGeneSys.

The move follows steady pressure from the National Institutes of Health (NIH), the Food and Drug Administration (FDA) and AIDS activist groups, each of which had challenged the value of the proposed singledrug trial.

Attempts to widen the trial into a comparison of different therapeutic vaccines floundered last year, and many scientists are in any case sceptical of the potential value of such vaccines (see Nature 363, 294; 1993).

A sum of $\$ 20$ million was added to a congressional spending bill in 1992 to pay for the trial, after intense lobbying by MicroGeneSys. But the wording of the bill allowed the money to revert to other Army AIDS research if DoD, NIH and the FDA agreed that the trial should not proceed, and this has now happened. Colin Macilwain 